\title{
Gross Morphology, Histology and Ultrastructure of the Nymphal Ileum of Conocephalus (Xiphidion) fuscus fuscus (Fabricius, 1793) (Orthoptera, Tettigoniidae)
}

\author{
Damla Amutkan Mutlu' ${ }^{\text {(D), Irmak Polat }}{ }^{2}$ (D), Zekiye Suludere' ${ }^{1}$ \\ 'Gazi University, Faculty of Science, Department of Biology, Ankara, Turkey \\ ${ }^{2}$ Çankırı Karatekin University, Faculty of Science, Department of Biology, Çankırı, Turkey
}

ORCID IDs of the authors: D.A.M. 0000-0002-4780-8520; I.P. 0000-0001-7230-4589; Z.S. 0000-0002-1207-5814

Please cite this article as: Amutkan Mutlu D, Polat I, Suludere Z. Gross Morphology, Histology and Ultrastructure of the Nymphal Ileum of Conocephalus (Xiphidion) fuscus fuscus (Fabricius, 1793) (Orthoptera, Tettigoniidae). Eur J Biol 2020; 79(1): 7-13. DOI: 10.26650/EurJBiol.2020.0040

\begin{abstract}
Objective: The alimentary canal is composed of the foregut, the midgut, and the hindgut in insects. The hindgut is the region where the reabsorption of the water and some ions occur and the feces are generated. The hindgut is generally divided into 3 parts as the ileum, the colon and the rectum in insects. The morphological and fine structures of these parts can be used as the taxonomical character. The aim of this study is to investigate the fine structure and morphology of the ileum in the last instar nymph of Conocephalus (Xiphidion) fuscus fuscus (Fabricius, 1793) (Orthoptera, Tettigoniidae).
\end{abstract}

Materials and Methods: In this study, morphology, histology, and ultrastructure of the ileum in the last instar nymphal C. fuscus fuscus were examined by stereomicroscope, light microscope, scanning electron microscope, and transmission electron microscope.

Results: Ileum is a tube-like structure, which is situated between the midgut and the colon. The wall of the ileum is composed of muscle tissue, connective tissue, epithelial tissue, and cuticular intima from the outermost to the innermost. Those singlelayered epithelial cells have globular nuclei, and some granulated endoplasmic reticulum can be observed in photographs. Besides, the regenerative cells groups called regenerative nidi are clear in some basal regions of the epithelial layer.

Conclusion: The general morphology and structure of the nymphal ileum in C. fuscus fuscus have some differences with the insects belonging to Orthoptera orders, but its histological, cytological, and fine structure are very alike.

Keywords: Digestive system, hindgut, ileum, light microscope, electron microscope

\section{INTRODUCTION}

The alimentary system of the insect is a structure which continues from the mouth to the end of the anus. The digestive system is basically divided into three regions in insects. These regions are the foregut, the midgut, and the hindgut (1-13). The foregut contains the esophagus, the pharynx, the crop, and the proventriculus. The midgut consists of the gastric caecum and the ventriculus. The hindgut is divided into three parts: the ileum, the colon, and the rectum. The ileum has an ectodermal origin, and the inside of the epithelium is lined by a cuticle (14-18).
The Malpighian tubules and the hindgut interoperate in excretory system of terrestrial insects. The primary isosmotic filtrate is produced by the Malpighian tubule cells, and then it is discharged in the lumen of ileum. The volume and composition of this filtrate starts to modify in the ileum lumen. The main role of the ileum in insects, as the intermediate step of the excretory system, is secretion, food digestion, and reabsorption of the water, ions, and metabolic residues $(16,18-31)$. Besides, in some insects such as Schistocerca gregaria (Orthoptera: Acrididae), the ileum contributes to the osmoregulation (32). 
Conocephalus (Xiphidion) fuscus fuscus (Fabricius, 1793) (Tettigoniidae), which can be found in parts of France, Sweden, Kazakhstan, Northern Africa, Bulgaria, Germany, Romania, Spain, Iran, Pakistan, Switzerland, Italy, Middle Asia, the Netherlands, and Turkey, is a species that belongs to Orthoptera order. The increase in the global climate in recent years has had a highly significant impact on the spread of this species. C. fuscus fuscus is a phytophagus species which feeds primarily on grasses $(33,34)$.

Since the studies regarding the histology and ultrastructure of the ileum in insects are very limited, we aimed to examine the structure of the ileum of the nymphal $C$. fuscus fuscus, whose digestive system has not been studied at the level of light and electron microscopy. We hope that the data obtained in this study will contribute to various experimental taxonomical, histological, and ultrastructural studies about insect tissues.

\section{MATERIALS AND METHODS}

The 10 male and 10 female last instar nymphal individuals of $C$. fuscus fuscus (Fabricius, 1793) (Orthoptera, Tettigoniidae) were collected from the terrains around the Ankara-Çankırı road in June 2017-2018. Samples brought to laboratory were anesthetized with ethyl acetate fumes first and the digestive canal was dissected out in physiological water under the stereomicroscope (Olympus SZX7).

For the scanning electron microscope (SEM) examinations, specimens were fixed in $5 \%$ glutaraldehyde. After fixation, the specimens, washed with phosphate buffer, were dehydrated in an ascending series of ethanol. Then, they were dried with a critical point dryer (Polaron CPD 7501), taken on SEM stubs, and coated with gold in a sputter coater (Polaron SC 502). The coated specimens were examined with JEOL JSM 6060 SEM at $10 \mathrm{kV}$ at Gazi University, Faculty of Science.

For the transmission electron microscope (TEM) examinations, specimens were post-fixed in $1 \% \mathrm{OsO}_{4}$ after pre-fixation in $5 \%$ glutaraldehyde. After rinsing with phosphate buffer, the specimens were dehydrated in ascending ethanol concentrations, and then embedded in Araldite. Ultra-thin sections were cut with Leica EM UC6 ultramicrotome and stained with lead citrate and uranyl acetate. The sections were examined with JEOL JEM 1400 TEM at $80 \mathrm{kV}$ and photographed Gazi University, Faculty of Science.

For the light microscopy (LM), semi-thin sections were cut with ultramicrotome from Araldite blocks prepared for TEM examinations and stained with $1 \%$ methylene blue. The stained sections were observed under a light microscope (Olympus BX51) and photographed.

\section{RESULTS}

The alimentary canal in the last instar nymphal $C$. fuscus fuscus is composed of three main parts as the foregut, the midgut, and the hindgut (Figure 1). The hindgut is divided into three regions called ileum, colon and rectum. The ileum is a short and thick tubular structure and located between midgut and colon (Figure 2). The

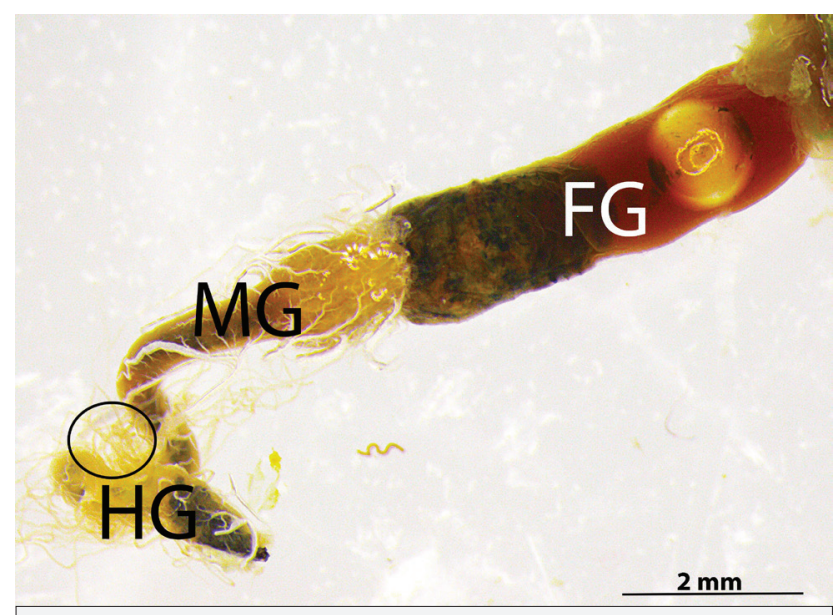

Figure 1. The general view of the alimentary canal in C. fuscus fuscus. Foregut (FG), midgut (MG), hindgut (HG) and Malpighian tubules (encircled) (Stereomicroscope).

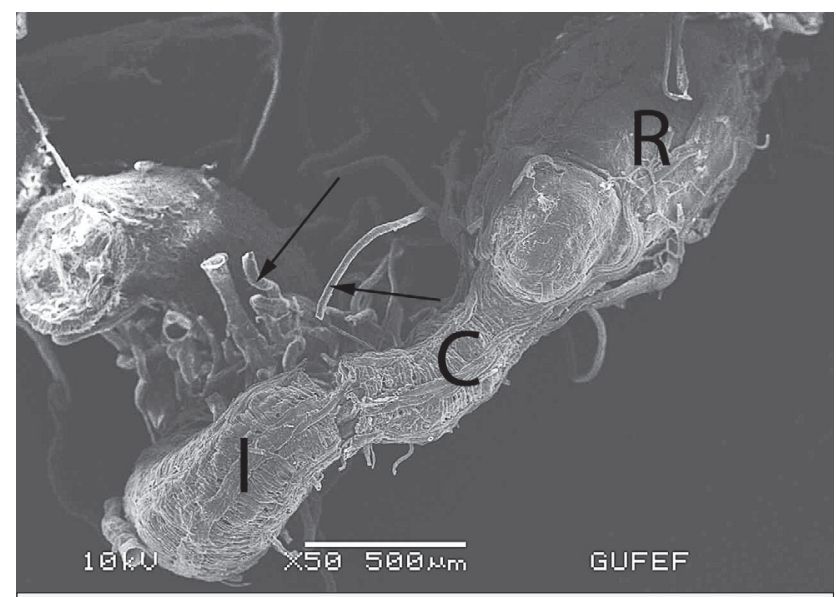

Figure 2. The general view of the hindgut in C. fuscus fuscus. Ileum (I), colon (C), rectum (R) and Malpighian tubules (arrows). SEM

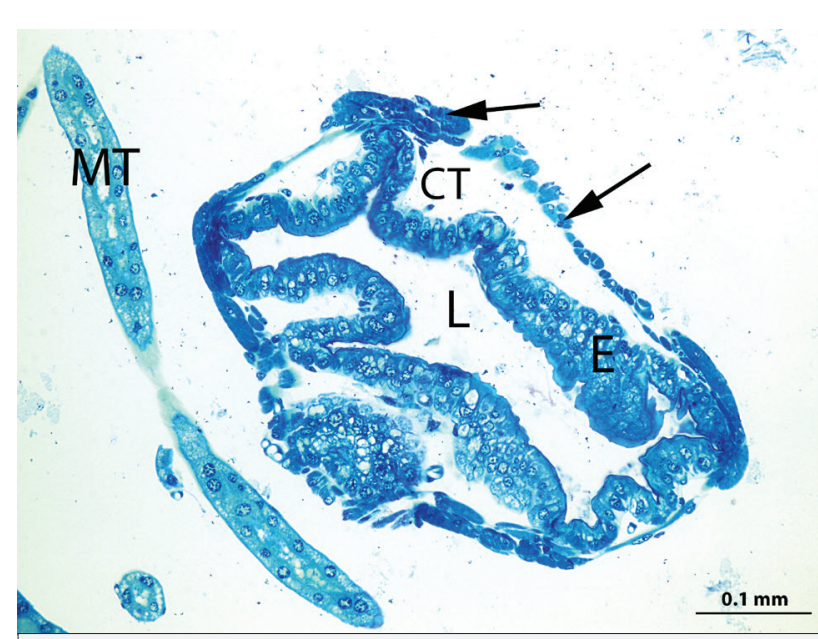

Figure 3. The semi-thin section of the ileum. Epithelial layer (E), muscle tissue (arrows), Malpighian tubules (MT), connective tissue (CT) and lumen (L). Light microscope, Methylene blue, x200 
Malpighian tubules are connected to the alimentary canal at the region where the midgut-ileum junction is (Figures 1 and 2).

In the cross-sections, it was seen that the ileum wall consists of single layer cubic epithelial tissue as the innermost, connective tissue in the middle, and muscle tissue as the outermost (Figures 3-7). There is a thin cuticular intima layer surrounding the lumen, the innermost above the epithelial layer (Figures 4-7).

Rather large and rounded nuclei are found in the middle of the epithelial cells (Figures 4, 7 and 8). Besides, granulated endoplasmic reticulum in the cytoplasm is visible in TEM photographs (Figure 8). It is observed that there is a connection between the outer membrane of the nucleus and granulated endoplasmic reticulum (Figure 8).

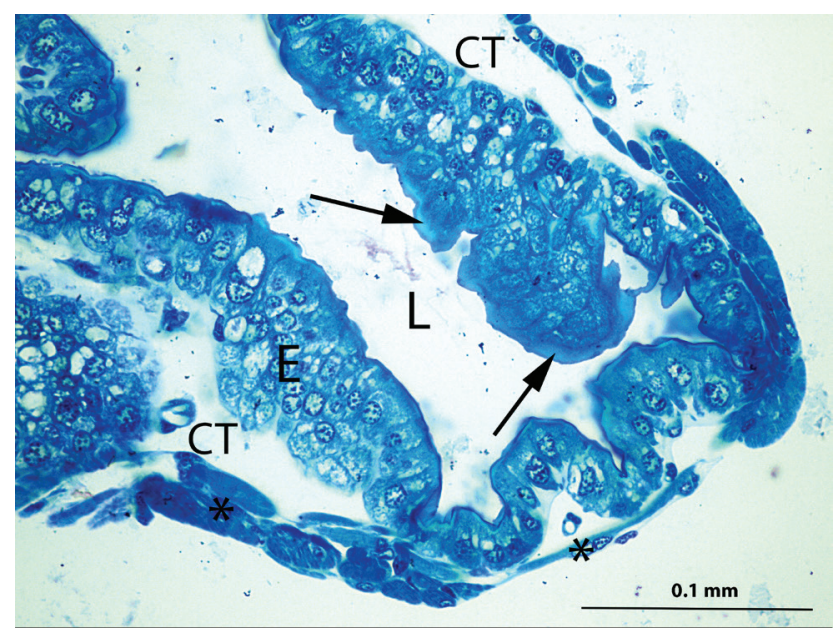

Figure 4. The semi-thin section of the ileum. Epithelial layer (E), muscle tissue (asterix), cuticular intima (arrows), connective tissue (CT) and lumen (L). Light microscope, Methylene blue, x400

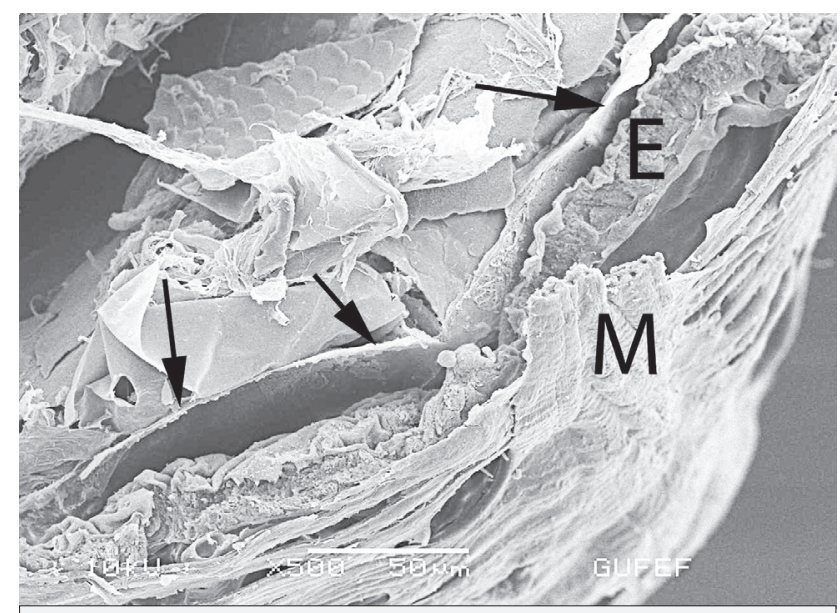

Figure 5. SEM photograph of the ileum in C. fuscus fuscus. Epithelial tissue (E), muscle tissue (M) and cuticular intima (arrows).

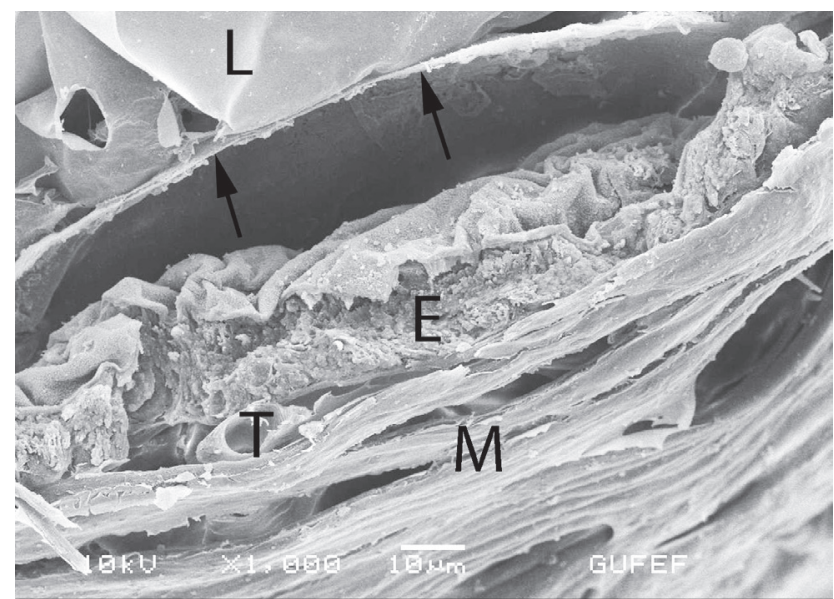

Figure 6. SEM photograph of the ileum in C. fuscus fuscus. Epithelial tissue (E), muscle tissue (M), lumen (L), trachea (T) and cuticular intima (arrows).

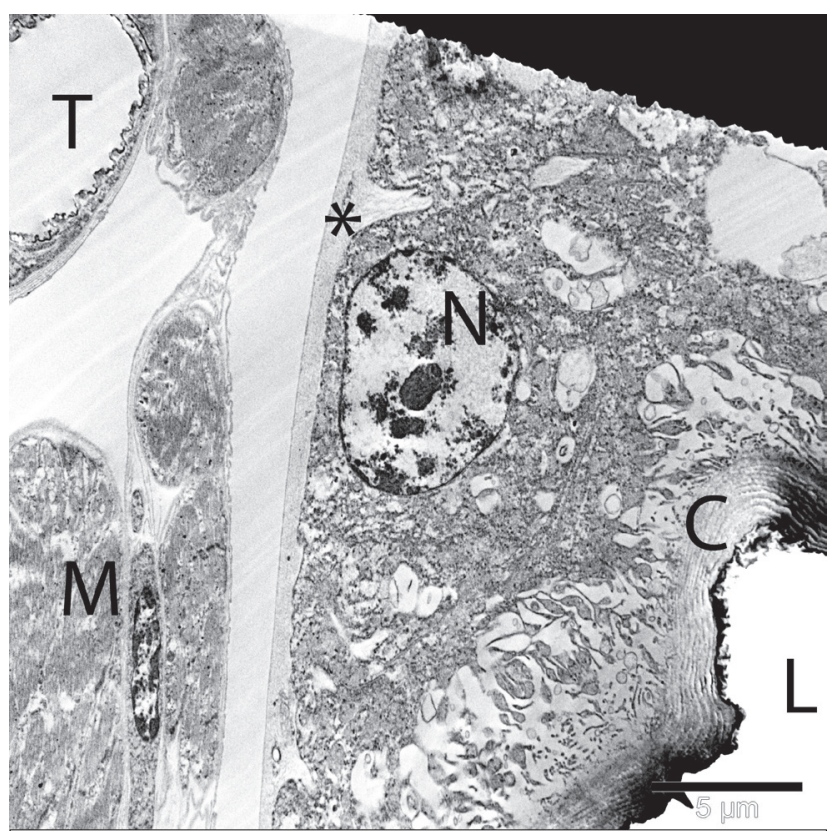

Figure 7. The thin section of the ileum. Nucleus (N), cuticular intima (C), lumen (L), basal lamina (asterix), muscle tissue (M) and trachea (T). TEM

In SEM photographs, the apical side of the epithelial cells looks undulated and indented (Figures 9 and 10) and have numerous knobby protrusions on the surface facing the cuticular intima (Figure 10). In TEM photographs, this structure looks as if it has some dispersed and nonuniform invaginations going toward the cytoplasm above the cuticular intima (Figure 11).

The nidi, which are regenerative cell groups, are located in basal region of epithelial layer. The regenerative cells have denser cytoplasm as regards electron comparing to the epithelial cells 
Eur J Biol 2020; 79(1): 7-13

Amutkan Mutlu et al. The Nymphal Ileum of C. fuscus fuscus

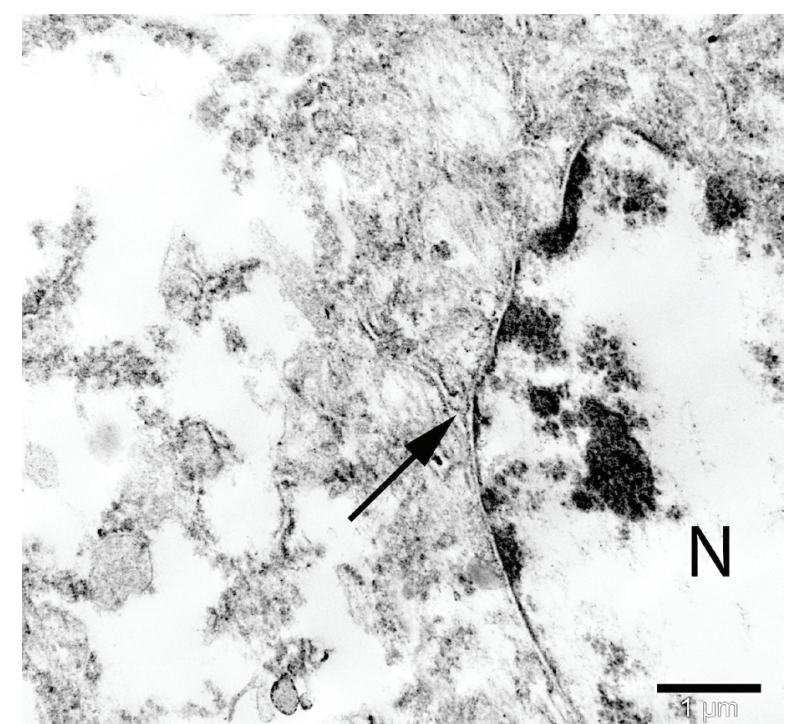

Figure 8 . The thin section of the ileum. Nucleus $(\mathrm{N})$ and the connection between the granulated endoplasmic reticulum and the outer membrane of the nucleus (arrow) in the epithelial cell. TEM

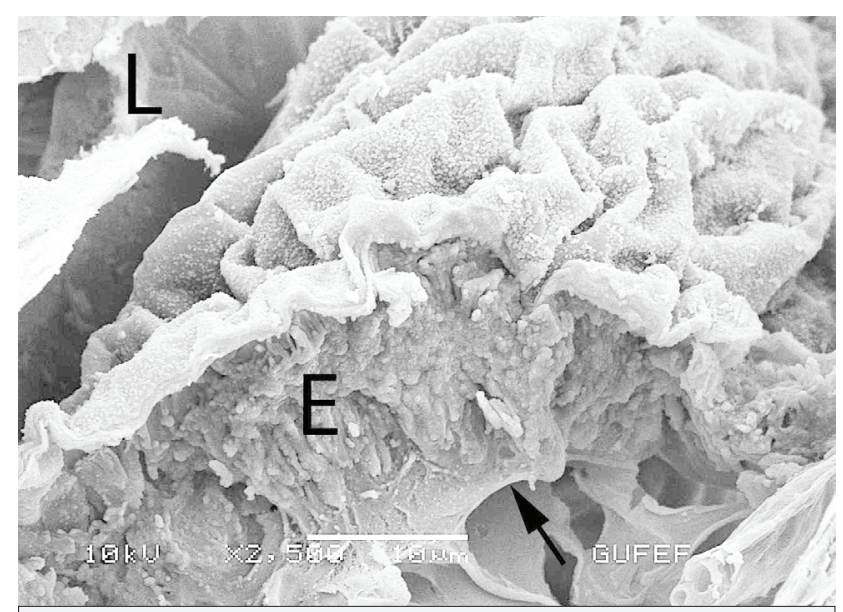

Figure 9. SEM photograph of the ileum wall. Epithelial layer (E), basal lamina (arrow) and lumen (L).

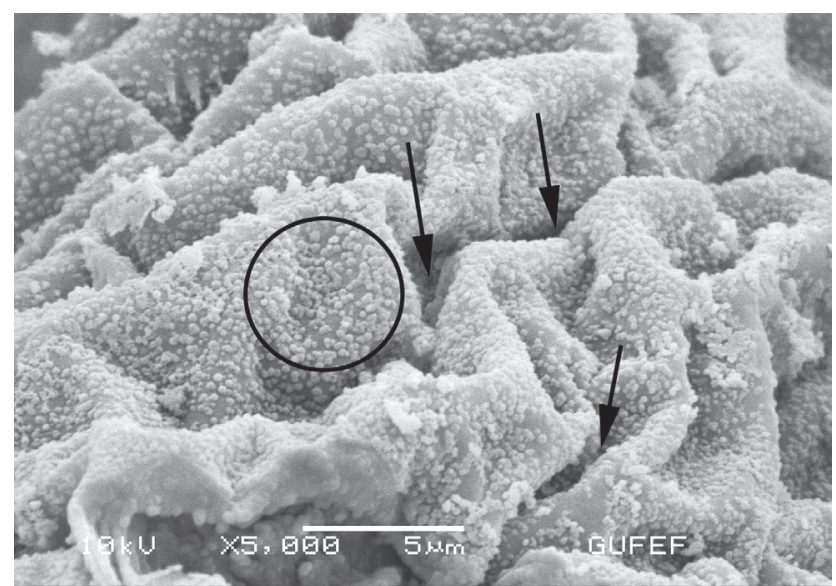

Figure 10. The apical surface of the epithelial layer. Undulated areas of apical region (arrows) and knobby protrusions (encircled). SEM

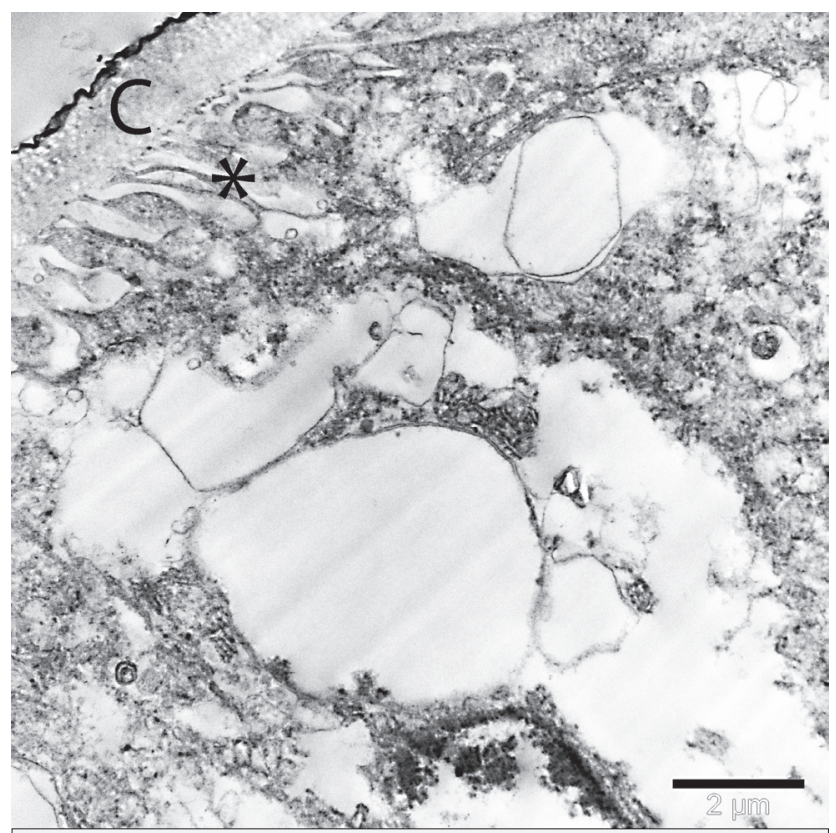

Figure 11. Dispersed and nonuniform invaginations (asterix) go toward the cytoplasm above the cuticular intima (C). SEM

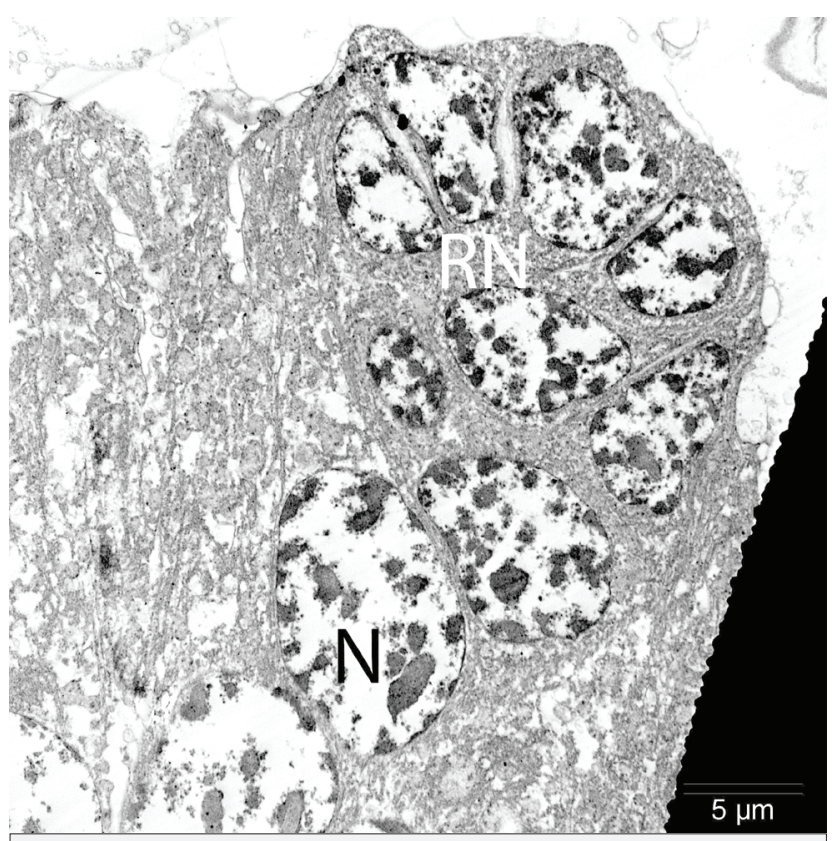

Figure 12. The thin section of the ileum showing the regenerative cell nidi (RN), which is composed of several regenerative cells and nucleus $(\mathrm{N})$ in epithelial cells. TEM

(Figure 12). The connective tissue recesses into the epithelial layer and thus the epithelial layer gains undulated structure (Figures 3 and 4). Epithelial cells rest on a thin basal lamina (Figures 7 and 9). The thin muscle tissue surrounds the outer surface of the ileum (Figures 4, 5 and 7). The trachea, which is situated in the connective tissue and outer side of the muscle tissue, can be observed in the cross sections of the ileum (Figures 6 and 7). 


\section{DISCUSSION}

In the insects, the digestive system consists of three regions: the foregut, the midgut, and the hindgut, while each region can be divided within itself $(13,17)$. The hindgut generally consists of the ileum, the colon, and the rectum $(17,35)$. However, in some insects such as Catopsilla pomona (Fabricius, 1758) (Lepidoptera: Pieridae) the hindgut is composed of two subparts as the ileum and the rectum (29). The ileum, which is the first part of the hindgut, can be divided into different parts in different insect groups (36). For example, in Formica nigricans (Hymenoptera, Formicidae), the ileum is divided into proximal, middle, and distal ileum (37). In Cephalodesmius armiger (Coleoptera, Scarabaeidae), larvae of Anticarsia gemmatalis (Lepidoptera, Noctuidae), Melanogryllus desertus (Orthoptera, Gryllidae), Poecilimon cervus (Orthoptera, Tettigoniidae) and Graphosoma lineatum (Heteroptera, Pentatomidae), the ileum consists of a single region $(2,17,18,35,37,38)$. When the ileum morphology of the last instar nymphal $C$. fuscus fuscus (Orthoptera) is compared with the other species, there is no compartment.

The ileum in Cenocorixa bifida (Hung.) (Hemiptera, Corixidae) is composed of two distinct areas that can be observed in TEM photographs of cross sections of the ileum. These areas are a ventral squamous epithelium and a dorsolateral columnar epithelium consisted of extremely large cells. The arrangement of the columnar epithelium forms a structure called as ileac pad. Although, the ileum in the last instar nymphal $C$. fuscus fuscus has no structure as in C. bifida (39).

In the cross sections of the ileum in the last instar nymphal $C$. fuscus fuscus the epithelial layer has infoldings on the apical side of the epithelium that can also be observed in Locusta migratoria (Orthoptera, Acrididae) and C. bifida. The epithelial cell layer also has finger-like invaginations into the lumen in $M$. desertus (18,20,39).

In some insects, the ileum has symbiotic bacteria $(40,41)$. It has been thought that the presence of bacteria in the ileum contributes to digestion by increasing digestibility of carbohydrates. The symbiotic bacteria localized on invaginations which at the apical side facing the lumen of the epithelial layer in the ileum of Gryllus bimaculatus (Orthoptera, Gryllidae) and Acheta domestica (Orthoptera, Gryllidae) was described in the studies of Ulrich et al. (1981) and Woodring and Lorenz $(2007)(42,43)$. In our study, we couldn't observe the symbiotic bacteria of the ileum lumen in the last instar nymphal C. fuscus fuscus.

The ileum epithelium of different species has different cell types. While the proximal ileum of $F$. nigricans has simple pyramidal epithelial cells, the middle ileum of the same species has simple cubic epithelial cells (36). Although the ileum epithelium has a single layer of cylindrical cell type in $M$. desertus, L. migratoria, and C. armiger, the ileum structure of larvae of $A$. gemmatalis consists of squamous epithelial cells $(2,17,20,37)$. The cells of the nymphal $C$. fuscus fuscus have a monolayer cubic epithelium similar to the ileum epithelium of $P$. cervus (35).
In general, the regenerative cells groups, called nidi, are shown in the midgut epithelium in insects. The new cells that grow from small regenerative cells in the midgut can replace cells lost through age, wear, and loss through apocrine or holocrine secretion (35,44-46). Regenerative cells lie near the base of the epithelial cells in larval Diptera, Lepidoptera, and Orthoptera. On the other hand, in some orders as Coleoptera, these cell groups are located at the apical side of the mature cells through the gut muscle layers (47). In our results, regenerative cell nidi were observed at the basal side of the epithelial layer of ileum in the last instar nymphs of $C$. fuscus fuscus. This may be due to the high requirement for regeneration of the ileum due to being in one of the stages of development.

The innermost layer of the ileum of nymphal $C$. fuscus fuscus shows an intima which has a cuticular layer and is folded along the epithelial cell layer. The cuticular intima layer is similar to the one observed in the ileum of P. cervus, C. bifida, Apis mellifera (Hymenoptera, Apidae), L. migratoria, Pylaemenes mitratus (Phasmatodea, Heteropterygidae), and C. pomona, which were compared in this study. The cuticular layer is thin in the last instar nymphal C. fuscus fuscus, Cephalotes pusillus (Hymenoptera, Formicidae), Cephalotes clypeatus (Hymenoptera, Formicidae), and Cephalotes atratus (Hymenoptera, Formicidae). The thickness of the cuticular layer is related to the roles of the ileum in absorption in these insects $(13,16,20,29,35,39,48)$.

The outer surface of the epithelial cell layer is surrounded by layers of circular and longitudinal muscles in C. fuscus fuscus, $C$. pusillus, C. clypeatus, and C. atratus; however, while the muscle tissue of ileum in C. pusillus, C. clypeatus, and C. atratus is thick, the one in the last instar nymphal $C$. fuscus fuscus is rather thin in some regions, and other regions have medium thickness. The ileum in $M$. desertus has only circular muscle layer surrounding the ileum wall $(16,18)$.

\section{CONCLUSION}

This study was conducted to provide a fundamental knowledge about the last instar nymphal $C$. fuscus fuscus. This species will contribute to the data on the families of Orthoptera and the other orders. Future comparative taxonomical, histological, and ultrastructural studies about the alimentary canals of insects can be conducted between other species of different insect orders.

Peer-review: Externally peer-reviewed.

Author Contributions: Conception/Design of study: D.A.M., I.P., Z.S.; Data Acquisition: D.A.M., I.P., Z.S.; Data Analysis/Interpretation: D.A.M., I.P., Z.S.; Drafting Manuscript: D.A.M., I.P., Z.S.; Critical Revision of Manuscript: D.A.M., I.P., Z.S.; Final Approval and Accountability: D.A.M., I.P., Z.S.; Technical or Material Support: Z.S.; Supervision: Z.S..

Conflict of Interest: The authors declare that they have no conflicts of interest to disclose. 
Financial Disclosure: There are no funders to report for this submission.

Acknowledgements: We express our thanks to Prof. Dr. Mustafa ÜNAL (Bolu Abant İzzet Baysal University, Faculty of Arts and Sciences, Biology Department) for helping in the species diagnosis and to Gazi University Academic Writing and Research Center for their help and support in the proofreading of the current study.

\section{REFERENCES}

1. Lee WY, Chen ME, Lin TL. Morphology and ultrastructure of the alimentary canal of oriental fruit fly Bactrocera dorsalis (Hendel) (Diptera: Tephritidae) (I): the structure of the foregut and cardia. Zool Stud 1998; 1(37): 95-101.

2. Levy SM, Falleiros ÂM, Moscardi F, Gregório EA, Toledo LA. Morphological study of the hindgut in larvae of Anticarsia gemmatalis Hübner (Lepidoptera: Noctuidae). Neotrop Entomol 2004; 33(4): 427-31.

3. Levy SM, Falleiros ÂM, Moscardi F, Gregório EA, Toledo LA. UItramorphology of digestive tract of Anticarsia gemmatalis (Hübner, 1818) (Lepidoptera: Noctuidae) at final larval development. Semina: Ciências Agrárias 2008; 29(2): 313-21.

4. Bution ML, Caetano FH, Britto FB, Gomes GT, Zara FJ. Histology and histochemistry of the ventriculus of Dolichoderus (=Monacis) bispinosus (OLIVIER, 1792) (Hymenoptera: Formicidae). Micron 2006; 37(3): 249-54.

5. Boonsriwong W, Sukontason K, Olson JK, Vogtsberger RC, Chaithong $U$, Kuntalue $B$, et. al. Fine structure of the alimentary canal of the larval blow fly Chrysomya megacephala (Diptera: Calliphoridae). Parasitol Res 2007; 100(3): 561-74.

6. Rubio G, José D, Bustillo P, Alex E, Vallejo E, Luis F, et. al. Alimentary canal and reproductive tract of Hypothenemus hampei (Ferrari) (Coleoptera: Curculionidae, Scolytinae). Neotrop Entomol 2008; 37(2): 143-51.

7. Serrão JE, Ronnau M, Neves CA, Campos LA, Zanuncio JC. Ultrastructure of anterior midgut region of corbiculate bees (Hymenoptera: Apidae). Ann Entomol Soc Am 2008; 101(5): 915-21.

8. Fialho MD, Zanuncio JC, Neves CA, Ramalho FS, Serrão JE. Ultrastructure of the digestive cells in the midgut of the predator Brontocoris tabidus (Heteroptera: Pentatomidae) after different feeding periods on prey and plants. Ann Entomol Soc Am 2009; 102(1): 119-27.

9. Santos CG, Neves CA, Zanuncio JC, Serrão JE. Postembryonic development of rectal pads in bees (Hymenoptera, Apidae). Anat Rec 2009; 292(10): 1602-11.

10. De Sousa G, Scudeler EL, Abrahão J, Conte H. Functional morphology of the crop and proventriculus of Sitophilus zeamais (Coleoptera: Curculionidae). Ann Entomol Soc Am 2013; 106(6): 846-52.

11. Gonçalves WG, Fernandes KM, Barcellos MS, Silva FP, Magalhaes-Junior MJ, Zanuncio JC, et. al. Ultrastructure and immunofluorescence of the midgut of Bombus morio (Hymenoptera: Apidae: Bombini). Comptes Rendus Biologies 2014; 337(6): 365-72.

12. Polat I, Suludere S, Candan S. Histological and ultrastructural features of the rectum in Poecilimon cervus Karabağ, 1950 (Orthoptera: Tettigoniidae). Microsc Res Techniq 2017; 80: 195-201.

13. Harris MN, Azman S, Nurul Wahida O. Gross anatomy and histology of alimentary system of stick insect, Pylaemenes mitratus (Phasmid: Basillidae). Serangga 2019; 24(1): 151-8.
14. Wigglesworth VB. The Principles of Insect Physiology. 7th ed. London: Chapman and Hall; 1972.

15. Nation JL. Insect Physiology and Biochemistry. CRC Press Boca Raton $\mathrm{FL} ; 2002$.

16. Bution ML, Caetano FH. lleum of the Cephalotes ants: A specialized structure to harbor symbionts microorganisms. Micron 2008; 39: 897-909.

17. Çakıcı Ö. Histological and Ultrastructural Investigations on the Digestive System of Melanogryllus desertus Pallas (Orthoptera: Gryllidae). E.Ü. Fen Bilimleri Enstitüsü, Doktora Tezi. 2008.

18. Çakıcı Ö, Ergen G. Histological and ultrastructural investigations on hindgut of Melanogryllus desertus (Pallas, 1771) (Orthoptera: Gryllidae). German J Zool Res 2013; 1(1): 1-6.

19. Beams HW, Tahmisian TN, Devine RL. Electron microscope studies on the cells of the Malpighian tubules of the grasshopper (Orthoptera, Acrididae). J. Biophysic Biochem Cytol 1955; 1(3): 197-214.

20. Peacock AJ. Ultrastructure of the ileum of Locusta migratoria. J Morphol 1986; 188: 191-201.

21. Irvine B, Audsley N, Lechleitner R, Meredith J, Thomson B, Phillips J. Transport properties of locust ileum in vitro: effects of cyclic AMP. J Exp Biol 1988; 137: 361-85.

22. Prado MA, Montuenga LM, Villaro AC, Etayo JC, Polak JM, Sesma MP. A novel granular cell type of locust Malpighian tubules: ultrastructural and immunocytochemical study. Cell Tissue Res 1992; 268(1): 123-30.

23. Gaino E, Rebora M. The duct connecting Malpighian tubules and gut: an ultrastructural and comparative analysis in various Ephemeroptera nymphs (Pterygota). Zoomorphol 2000; 120(2): 99-106.

24. Acar G. Melanogryllus desertus (Pallas, 1771) (Orthoptera: Gryllidae)'ta Malpighi Tüpçüklerinin Morfoloji ve Histolojisi. E.Ü. Fen Bilimleri Enstitüsü, Yüksek Lisans Tezi. 2009.

25. Conti B, Berti F, Mercati D, Giusti F, Dallai R. The ultrastructure of Malpighian tubules and the chemical composition of the cocoon of Aeolothrips intermedius Bagnall (Thysanoptera). J Morphol 2010; 271(2): 244-54.

26. De Azeredo-Oliveira MT, da Silva TL, Mello ML. Mg2+-dependent ATPase activity in Malpighian tubules of Triatoma infestans Klug. Micron 2012; 43(2-3): 298-304.

27. Ferreira RA, Zacarin EC, Malaspina O, Bueno OC, Tomotake ME, Pereira AM. Cellular responses in the Malpighian tubules of Scaptotrigona postica (Latreille, 1807) exposed to low doses of fipronil and boric acid. Micron 2013; 46: 57-65.

28. Pal R, Kumar K. Malpighian tubules of adult flesh fly, Sarcophaga ruficornis Fab. (Diptera: Sarcophagidae): an ultrastructural study. Tissue Cell 2013; 45(5): 312-7.

29. Poolprasert P, Mongkolchaichana E, Senarat S, Kettratad J, Yenchum W, Angsirijinda W. Light microscopic observations of the mesentero-proctodeal regions in adult Catopsilla pomona (Fabricius, 1758) (Lepidoptera: Pieridae). Suranaree J Sci Technol 2015; 22(1): 99-103.

30. Giglio A, Perrotta ID, Brandmayr P. Exosomes: Ultrastructural evidence in epithelial cells of Malpighian tubules. Micron 2017; 100: 34-7.

31. Rivera-Vega L, Mikó I. Know your insect: Malpighian tubules in Trichoplusia ni (Lepidoptera: Noctuidae). Res Ideas Outcomes. 2017 Feb 01. doi: 10.3897/rio.3.e11827 e11827.

32. Gullan PJ, Cranston PS, editors. İç anatomi ve fizoloji. Böcekler: entomolojinin ana hatları. Ankara: Nobel; 2012.

33. Ragge DR. Grasshoppers, Crickets and Cockroaches of the British Isles. London: F Warne and Co; 1965. 
34. Sadiq S, Panhwar WA, Sultana R, Saeed M, Wagan SA, Ahmed S. New record of Conocephalus (Anisoptera) fuscus (Fabricius, 1793) (Conocephalinae: Tettigoniidae: Orthoptera) from Pakistan. J Entomol Zool Stud 2017; 5(3): 1431-4.

35. Polat I. The ultrastructural features of the digestive, excretory, female and male reproductive systems of Poecilimon cervus Karabag, 1950. G.Ü. Fen Bilimleri Enstitüsü, Doktora Tezi. 2016.

36. Villaro AC, Garayoa M, Lezaun MJ, Sesma P. Light and electron microscopic study of the hindgut of the ant (Formica nigricans, Hymenoptera): I. structure of the ileum. J Morphol 1999; 242(3): 189-204.

37. Lopez-Guerrero Y. Anatomy and histology of the digestive system of Cephalodesmius armiger Westwood (Coleoptera, Scarabaeidae, Scarabaeinae). Coleop Bull 2002; 56(1): 97-107.

38. Amutkan D, Suludere Z, Candan S. Ultrastructure of digestive canal of Graphosoma lineatum (Linnaeus, 1758) (Heteroptera: Pentatomidae). J Entomol Res Soc 2015; 17(3): 75-96.

39. Jarial MS; Scudder GGE. The morphology and ultrastructure of the Malpighian tubules and hindgut in Cenocorixa bifida (Hung.) (Hemiptera, Corixidae). Z Morphol Oekol Tiere 1970; 68(4): 269-99.

40. Chapman RF. The Insects: Structure and Function. 5th ed. New York: Cambridge University Press; 2013.
41. Klowden MJ. Physiological Systems in Insects. 3rd ed. London: Academic Press; 2013.

42. Ulrich RG, Buthala DA, Klug MJ. Microbiota associated with the gastrointestinal tract of the common house cricket, Acheta domestica. Appl Environ Microbiol 1981; 41(1): 246-54.

43. Woodring J, Lorenz MW. Feeding, nutrient flow, and functional gut morphology in the cricket Gryllus bimaculatus. J Morphol 2007; 268: 815-25.

44. Illa-Bochaca I, Montuenga LM. The regenerative nidi of the locust midgut as a model to study epithelial cell differentiation from stem cells. J Exp Biol 2006; 209: 2215-23.

45. Park MS, Park P, Takeda M. Starvation induces apoptosis in the midgut nidi of Periplaneta americana: a histochemical and ultrastructural study. Cell Tissue Res 2009; 335: 631-8.

46. Çakıcı Ö, Ergen G. Histologic description of midgut in Melanogryllus desertus (Pallas, 1771) (Orthoptera: Gryllidae). Biharean Biol 2012; 6(2): 108-111.

47. Nation JL. Insect Physiology and Biochemistry. 2nd ed. Florida: CRC Press; 2008.

48. Gonçalves WG, Fernandes KM, Santana WC, Martins GF, Zanuncio JC, Serrão JE. Post-embryonic changes in the hindgut of honeybee Apis mellifera workers: Morphology, cuticle deposition, apoptosis, and cell proliferation. Dev Biol 2017; 431(2): 194-204. 